\title{
Traditional capacity for weather prediction, variability and coping strategies in the front line states of Nigeria
}

\author{
Shukurat Adunni Sanni ${ }^{1}$, Kolapo Olatunji Oluwasemire ${ }^{2 * \#}$, Nnadozie Okonkwo Nnoli ${ }^{3 \dagger}$ \\ ${ }^{\mathbf{1}}$ Department of Agricultural Economics and Rural Sociology, Institute for Agricultural Research/Ahmadu Bello University, Zaria, \\ Nigeria \\ ${ }^{2}$ Department of Soil Science, Faculty of Agriculture/Ahmadu Bello University, Zaria, Nigeria; \\ *Corresponding Author: kooluwasemire@yahoo.com \\ ${ }^{3}$ Nigerian Meteorological Agency, Lagos, Nigeria
}

Received 22 March 2012; revised 28 April 2012; accepted 18 May 2012

\section{ABSTRACT}

This paper is based on the results of a pilot project conducted to strengthen Nigerian Meteorological Agency's (NIMET) capacity to provide reliable planting date forecast in Nigeria. This aspect of the project aimed at understanding traditional knowledge base and farmers' prediction methods, community perceptions of impacts of rainfall variability, coping strategies and opportunities in Sokoto, Kano, Jigawa, Kaduna, Bauchi states of Nigeria. Based on prevalence of drought, a community was selected for survey in each of the five states. Semi-structured interview and focus group discussion were used to sources for information. The survey indicates that the farmers had good understanding of weather and climatic dynamics of their community. The farmers in the study locations characterize a year into five seasons based on the atmospheric temperature as felt by the body, changes in wind direction, farming activities, and the behavioral changes of some animal and birds and phenological changes in plant species. Rainfall variability in the community has altered the farming systems, either in terms of changes in cropping pattern, elimination/reduction in the level of producing some crops or introduction of new crop varieties that are drought resistant and early maturing, and diversification of source of livelihood (non-farm activities). Impacts of rainfall variability in the communities were asserted to include; poor yield, low prices of crop/livestock, low dowry for their daughters, high cost

\footnotetext{
"Present Address: Department of Agronomy, University of Ibadan, Ibadan, Nigeria.

†Present Address: Department of Meteorology, Federal University of Technology, Akure, Nigeria.
}

of labor as a result of migration to urban centers, inadequate water for dry season farming, low income, low standard of living, and high level of poverty. Farmers recommended an integration of traditional proven methods of rainfall prediction with scientific methods to evolve reliable forecast that will reduce risks in their rainfed farming systems.

Keywords: Traditional Knowledge Base; Rainfall Prediction; Crop Production; Northern Nigeria

\section{INTRODUCTION}

Crop production in Nigeria is essentially rainfed. Agriculture is therefore heavily dependent on the seasonal characteristics of rainfall which has been shown to diminish in amount and duration as one move from the south to the northern part of the country. Current evidence clearly shows that rainfall variability is a real threat and that the need for action today cannot be ignored [1-3]. Agricultural development has been affected by natural climate variability and extreme climate events which have caused significant decline in productivity resulting in food insecurity and poverty among rural communities. Precipitation changes are currently insufficient for many crops that water scarcity increasingly constrains production [4]. Analyses conducted by the Nigerian Meteorological Agency (NIMET), have found that drought disasters are significantly more probable in recent times [5,6]. While droughts are frequent, the rate of growth in agriculture has been one of the slowest in terms of production and productivity $[7,8]$. The pressure also includes the intensified use of more fragile land resources, leading to accelerated degradation of the soil to desert-like conditions, thereby reducing sustainable agricultural production [9]. Today, Nigeria has less than $9 \%$ 
of the total cropped area under irrigation. Hence, the rural population is very vulnerable to rainfall fluctuations. Despite the economic hardship and the prolonged effects of drought and desertification, the people in the drought prone areas of northern Nigeria possess great reliance, patience, and adaptive capacity [10]. Environmental degradation caused by successive years of poor rainfall amount/distribution and recurrent droughts is exacerbated by combined effects of natural population growth and immigration from neighboring resource-poorer countries. In this study we focused on the vast traditional knowledge of the farmers on rainfall prediction and their understanding of its reliability through their observation, experience and practice in the field. Understanding them is not only necessary to communicate the scientific forecast, since it is learnt and identified by farmers within a cultural context and the knowledge base which follows specific language, belief and process. By perceiving such a knowledge base, it may facilitates social interaction and promote acceptance of scientific forecast among the farmers.

\section{MATERIALS AND METHODS}

Five communities within $5-70 \mathrm{~km}$ from the nearby main town were purposively selected from each of the Agricultural Development Program (ADP) zones in each State based on reported high incidence of dry spell after the onset of rains. These sites are Gangara in Kaduna state $\left(11^{\circ} 20^{\prime} \mathrm{N}, 07^{\circ} 23^{\prime} \mathrm{E}\right.$; $660 \mathrm{~m}$ above sea level) about 37 $\mathrm{km}$ north of Zaria on the Zaria-Funtua road; Shantake $\left(12^{\circ} 10^{\prime} \mathrm{N}, 08^{\circ} 31^{\prime} \mathrm{E}\right.$; $469 \mathrm{~m}$ above sea level) in Makoda local government area of Kano state, Nigeria. The village is about $50 \mathrm{~km}$ north of Kano town along the Kano-Daura highway; Yan'dutse in Jigawa state $\left(12^{\circ} 11^{\prime} \mathrm{N}, 9^{\circ} 15^{\prime} \mathrm{E}\right.$; $397 \mathrm{~mm}$ above sea level) about $95 \mathrm{~km}$ northeast of Kano and $70 \mathrm{~km}$ north of Dutse (Jigawa State Capital) along Kano-Gujungu high way; Kasarawa $\left(12^{\circ} 58^{\prime} \mathrm{N}, 05^{\circ} 12^{\prime} \mathrm{E}\right.$; $298 \mathrm{~m}$ above sea level) in Wamako local government area of Sokoto state, about $5 \mathrm{~km}$ south of Sokoto town and Dabarndak $\left(09^{\circ} 34^{\prime} \mathrm{N}, 10^{\circ} 00^{\prime} \mathrm{E}\right.$; $641 \mathrm{~m}$ above sea level) in Dass local government area of Bauchi state, Nigeria. The selected sites in Kaduna and Bauchi state are in the northern Guinea Savanna zone while those of Kano, Jigawa and Sokoto states are in the Sudan savanna agroecological zone. The community survey involved the characterization of the community in terms of the traditional prediction of onset of rains/planting season, consequences of wrong predictions of onset of planting season and coping strategies/opportunities. A village was purposively selected in each state with the assistance of the Sasakawa Global 2000 an NGO, Extension staff of the Agricultural Development Project (ADP), and researcher from the University within the state. The survey used participatory methodology tool like semi-structured interview with the community ( $25-60$ in attendance) and focus group discussion for studying the traditional knowledge basis on weather and climate prediction. The ages of people that participated in the community group interview ranged from $25-75$ years while the range for the focus group discussion was $45-75$ years. Themes and probing checklists were prepared in advance and the participants were guided in the discussion. A series of Participatory Rural Appraisal (PRA) exercises such as livelihood analysis, seasonal calendar of activities and priority ranking were organized with the community and focus group of selected individuals who seems to be most knowledgeable about traditional methods for rainfall predictions. Focus group discussion (FGD) was used to clarify the needs, constraints and coping strategies on weather and climate of the community. Through a process of triangulation, the views expressed in the FGD, community discussion were consolidated and analyzed using descriptive statistics.

\section{RESULTS AND DISCUSSION}

\subsection{Traditional Knowledge Basis and Farmers' Prediction Methods}

The survey indicates that the farmers had good understanding of weather and climate of their community. They have developed a variety of traditional indicators for predicting weather situation to make farm management decisions and those relating to other means of livelihoods (Table 1). The local prediction skills have evolved through observations and experience and passed down the generations through oral tradition. The Islamic scholars (Mallams) in these communities also acts as local weather experts, and even those communities that have access to scientific weather forecast will rather act based on the information from local experts and they asserted that it works for them. The farmers in the study locations characterized a year into four/five seasons based on the atmospheric temperature as felt by the body, wind directional changes, farming activities, and the behavioral patterns of some animal and birds as well as the phenological changes associated with some plant/tree species. The four/five seasons are: Damina, (rainy season), Kaka (harvesting season), Sanyi/hunturu (cold season), Rani (dry season) and Bazara (hot season).

The people used several indicators to predict the onset of rainfall and planting season in the community. The traditional forecast knowledge has been adapted to local conditions and its requirement is dependent on physical observations like behavior of birds, flowering or flushing times of some trees species, prevailing wind directions and cloud patterns. Breman and Kessler [11] reported that climatic factors (rainfall distribution, air humidity, wind direction and temperature) and site conditions are 
Table 1. Traditional knowledge base of farmer's decision processes during cropping season in the Northern Nigerian savanna.

\begin{tabular}{|c|c|c|c|c|c|}
\hline Season & $\begin{array}{c}\text { Period } \\
\text { /Duration }\end{array}$ & $\begin{array}{l}\text { Observation of weather } \\
\text { elements/Human reactions }\end{array}$ & $\begin{array}{l}\text { Behavior of animals } \\
\text { and birds }\end{array}$ & $\begin{array}{c}\text { Phenological changes in } \\
\text { plants/Tree species }\end{array}$ & Activities/Remarks \\
\hline $\begin{array}{c}\text { BASARA } \\
\text { (Hot season) }\end{array}$ & $\begin{array}{l}\text { March-May } \\
(\approx \approx 90 \text { days })\end{array}$ & $\begin{array}{l}\text { - High day time air } \\
\text { temperatures. } \\
\text { - Perspiration on human body } \\
\text { takes longer time to dry up } \\
\text { (increased atmospheric } \\
\text { humidity). } \\
\text { - Change in wind direction } \\
\text { eastwards in late May } \\
\text { indicative of possible } \\
\text { rainstorm within } 1 \text { - } 2 \text { weeks } \\
\text { of observation. } \\
\text { A period of consistently high } \\
\text { daily temperature for a } \\
\text { minimum of } 5 \text { days indicates } \\
\text { the commencement of rainy } \\
\text { season. }\end{array}$ & $\begin{array}{l}\text { - Appearance of wild } \\
\text { duck-like birds } \\
\text { (“Shamua") indicative of } \\
\text { rainstorm within } 2 \\
\text { weeks. } \\
\text { If army worms } \\
\text { (Spodoptera exempta or } \\
\text { S. littoralis) are observed } \\
\text { after planting, a period of } \\
\text { dry spell is imminent. } \\
\text { Appearance of } \\
\text { Chameleon on cultivated } \\
\text { field after rainfall } \\
\text { commencement is } \\
\text { indicative of a period of } \\
\text { dry spell. }\end{array}$ & $\begin{array}{l}\text { Season starts when } \\
\text { Locust bean tree } \\
\text { (Parkia biglobosa) starts } \\
\text { flowerings and ends when } \\
\text { its fruits are ripe and } \\
\text { ready for harvest. } \\
\text { - Complete defoliation of } \\
\text { "Gawo" (Fadherbia } \\
\text { albida) tree indicates the } \\
\text { commencement of rainy } \\
\text { season. } \\
\text { Baobao (Ceiba pentadra) } \\
\text { tree starts flowerings at } \\
\text { the start of rainy season. } \\
\text { Sprouting of } \\
\text { Dactyocteium aegytium } \\
\text { (“Burgali") indicative of } \\
\text { rainfall occurrence within } \\
3 \text { weeks of observation. }\end{array}$ & $\begin{array}{l}\text { - Land clearing } \\
\text { and preparation. } \\
\text { Clearing of } \\
\text { previous crop } \\
\text { stover, shrubs } \\
\text { and debris } \\
\text { commences. } \\
\text { Threshing of } \\
\text { crops before } \\
\text { planting. } \\
\text { Transportation of } \\
\text { manure and } \\
\text { household refuse } \\
\text { to the farm. } \\
\text { Planting starts } \\
\text { with the first } \\
\text { heavy rainfall i.e. } \\
\text { when ponding of } \\
\text { water occur in } \\
\text { furrows and } \\
\text { depressions on } \\
\text { the farm. }\end{array}$ \\
\hline $\begin{array}{l}\text { DAMINA } \\
\text { (Rainy } \\
\text { season) }\end{array}$ & $\begin{array}{l}\text { May-October } \\
(\approx \approx 180 \text { days })\end{array}$ & $\begin{array}{l}\text { Wind direction changes from } \\
\text { multi-directional and moves } \\
\text { eastwards } \\
\text { Reduction in day time air } \\
\text { temperatures and increasing } \\
\text { cloudiness }\end{array}$ & $\begin{array}{l}\text { - Guinea fowl starts laying } \\
\text { eggs at onset of rains and } \\
\text { lay daily when rains are } \\
\text { fully established } \\
\text { - Rains are well established } \\
\text { when crickets dig holes } \\
\text { and make loud chirping } \\
\text { courtship calls. } \\
\text { Termite's nuptial flights } \\
\text { occur when rains are fully } \\
\text { established. } \\
\text { Appearance of locust is } \\
\text { indicative of drought }\end{array}$ & $\begin{array}{l}\text { Flushing of tree species } \\
\text { Tamarandus indica and } \\
\text { Baobao indicate the full } \\
\text { commencement of rainy } \\
\text { season. }\end{array}$ & $\begin{array}{l}\text { Planting of crops, } \\
\text { weeding and } \\
\text { other agronomic } \\
\text { practices. }\end{array}$ \\
\hline $\begin{array}{c}\text { KAKA } \\
\text { (Harvesting } \\
\text { season) }\end{array}$ & $\begin{array}{c}\text { October- } \\
\text { January } \\
(\approx \approx 120 \text { days })\end{array}$ & $\begin{array}{l}\text { - } \text { Cessation of rains } \\
\text { - } \quad \text { Increase in day time } \\
\text { temperatures and sunshine } \\
\text { - } \text { Reduced cloudiness }\end{array}$ & & $\begin{array}{l}\text { - Flushing of "Gawo" } \\
\text { (Fadherbia albida) }\end{array}$ & $\begin{array}{l}\text { - All rainfed crops } \\
\text { are harvested } \\
\text { - Crop storage, } \\
\text { processing and } \\
\text { marketing } \\
\text { prevails } \\
\text { Land preparation } \\
\text { for dry season } \\
\text { (Fadama) and } \\
\text { irrigation } \\
\text { farming } \\
\text { commences. } \\
\end{array}$ \\
\hline $\begin{array}{c}\text { RANI } \\
\text { (Cold /Dry) } \\
\text { season) }\end{array}$ & $\begin{array}{l}\text { December- } \\
\text { March } \\
(\approx \approx 120 \text { days })\end{array}$ & $\begin{array}{l}\text { Prevailing dusty cloud } \\
\text { harmattan wind } \\
\text { - Low night and morning air } \\
\text { temperatures } \\
\text { - Harmattan haze/dusts }\end{array}$ & & & $\begin{array}{l}\text { Raising of fruits } \\
\text { and vegetable } \\
\text { seedlings for dry } \\
\text { season (Fadama) } \\
\text { and irrigation } \\
\text { farming. } \\
\text { - Trans-planting of } \\
\text { seedlings and } \\
\text { establishment of } \\
\text { dry season crops. }\end{array}$ \\
\hline
\end{tabular}

the most important determinants of the presence of foliage and fruits on the woody plants of the West African semi-arid region.

The most popular and reliable method of predicting possibility of onset of rainfall within a week or two, ac- cording to farmers is based on changes in wind direction from the west towards the east. If it rains before the wind changes direction, this rain is usually considered a false rain, and so farmers do not plant no matter the intensity of the rainstorm. The period when complete defoliation 
of the "Gawo" (Fadherbia albida) tree occurs is rated next in term of reliability of prediction in the community. Lastly, they also use a method that depends on counting days from the last effective rains of the previous season. It assumes that, rain is bound to fall in the $7^{\text {th }}$ month from the last effective rain of the previous year. However, if around that time rain falls without a change in wind direction, it is assumed to be a false rain. In addition to these local predictions knowledge base, the farmers in some states (Kano, Jigawa, and Kaduna) also have access to scientific forecast from their extension agents, radio and television, though they claim to depend more on their traditional forecast. Farmers use these predictions for land clearing and land preparation. Ridging starts after yet another heavy rain. Planting of drought resistant crops like millet, and sorghum also starts at this time. The documentation of farming systems with their complexities in relation to livelihood patterns have also been suggested to offer strategies for mitigation and adaptation to climate change [12]. Planting of other high value and drought sensitive crops (maize, soybean, groundnut and cassava) commences only when the rains are established (i.e. when rainfall is frequent and heavy enough to cause ponding on their fields). Farmer's claim that their method for predicting the start of rain is correct in 8 years of the last 10 years. However, they have no methods to predict dry spell that may set in after the rains have commenced. The occurrences of long dry spells lasting 2 to 3 weeks, which have caused considerable hard-ships, have been noticed in three out of the last ten years.

Onset of rains may triggers planting of drought tolerant crops such as millet (Pennisetum glaucum L.R. Br.) and sorghum (Sorghum bicolor). But farmers tarry to plant input intensive and drought sensitive food and cash crops. They wait for rains to establish and use following indicators to determine establishment of rain and onset of planting:

- It rains frequently with heavy thunder and lightning; the soil remains soft and moist for an extended period

- After sunset, reddish horizon reflects in the east, this usually comes along with rain.

- Termite's nuptial flight only occurs when the rains are fully established.

- Kulba (snake-like lizard) makes a lot of noise when rains are fully established.

- Cricket (Acheta domesticus) makes loud chirping courtship calls (noise) and dig holes.

- Appearance of a species of reptile which when mature looks like a lizard.

- Appearance of algae growth on walls of residential buildings.

- African Guinea fowl (Numida meleagris galeata) lays egg every day.
- Continuous croaking of toads (Bufo regularis) inside wells or under trees.

Once rains are established, planting may commence if the soil is moist (determined by using a local hoe called sungumi to dig the soil and determine the depth of moist soil) or after a heavy rainstorm. Farming communities surveyed agreed that their traditional forecasting methods often work for predicting the onset of rainfall and planting season but rarely for the distribution of rainfall within the year. The farmers' prediction skills have also improved over the years as people are actually trained in this act by traditional religious teachers within and outside the communities. In Kaduna state for instance, farmers look out for chameleon (Chamaeleo chamaeleon) on the field after the first heavy rain. If chameleons are observed, it is believed that it will take sometime before the next rain, in which case they have to wait for another heavy rain before planting. It was emphasized in Bauchi state that appearance of small army worms-Spodoptera exempta or S. littoralis (moth larvae) after early season rains indicates a possibility of dry spell. In south-eastern Kenya, the main indicators for farmers to start land preparation and planting were reported to include budding of certain trees, high temperature and relative humidity, animal behaviors, wind direction and the smell of rain [13]. These also form part of the important traditional knowledge systems on how farmers might respond to climate change. Some farmers also acknowledged having access to scientific weather forecast from radio, television and extension agents and these are used to supplement their own traditional forecasting methods Some stations even tell them when to start preparing their farmland. The information is used in complementing the traditional prediction methods. However, if the scientific weather forecast contradicts their own prediction, they take decision based on their own forecast.

\subsection{Community Perceptions on Impacts of Rainfall Variability}

Year-to-year rainfall variability is perceived as a major constraint to increased agricultural production. Farmers recalled that the seasons have become less predictable than in the past. Droughts are frequent - about 3 in every 10 years. Rainfall variability in the community has altered the farming systems, either in terms of changes in cropping pattern, elimination/reduction in the level of producing some crops or introduction of new crop varieties that are drought resistant and early maturing. Nyong et al. [14] also suggested the concept of integrating adaptation into mitigation strategies of climate change effects with adequate knowledge of the indigenous knowledge base. Relay cropping was a common practice in the community over ten years ago but this has been eliminated as a result of low distribution of rainfall and effort 
made to reduce competition for limited water resource and increase productivity of crop. For instance, the farmers used to cultivate millet and harvest before planting cowpea. Some farmers even use the proceeds from millet to farm cowpea. Now all these crops are intercropped on the same plot. Maiwa millet was a common crop in the community in the past but this has also been eliminated from their farming system due to the low yield of the available cultivars and early cessation of rains. Groundnut production has been reduced drastically in the community due pest and diseases problems, which was also attributed to poor distribution of rainfall in farmers' understanding. Early maturing and high yielding sorghum variety (yar Zaria) is now the most commonly used sorghum variety in the community due to reduction in rainfall amount. The following were identified as conesquences of delayed onset of rain and incorrectly predicted planting decision

- The farmers affirmed that in a bad year, replanting occurred as many as four times a year. In which case, farmer's who have already applied fertilizer may replant without another application if he cannot afford it. Apart from the additional cost of inorganic fertilizer, there may also be the need to source for seed and pay for labor (if using hired labor) leading to additional cost of production.

- Low yield: In case of delay in rainfall, the yield loss may not be appreciable if the rain resume early enough. However, if the length of growing season reduces drastically as result of the delay, it could cause a yield loss of up to $50 \%$. In case of drought, the yield loss could be as high as $90 \%$.

- Low rainfall could dry up sources of water for domestic use and for livestock. This also affects the health status of the people in the community as they revert on any source (clean or unclean) of water for domestic use. Common ailments resulting from inadequate water supply due to low rainfall are malaria, guinea worm, typhoid, and cholera.

- Delay in rainfall affect dry season farming, particularly where the people depends on residual soil water stored from the previous season rains.

- Severe drought in the community may also cause temporary migration to other communities or urban centre to farm or trade. It was reported that some of these migrants are the carriers of viruses causing ailments like HIV into the communities.

- Inadequate rainfall or water required for crop growth usually lead to poor quality of grains leading to poor milling and low prices and consequently low income and standard of living.

- Low rainfall affects growth of animals due to inadequate feed and water. This ultimately reduces their stock (sale of the animals at very low prices or move- ment of animals out of the community in search of feed and water).

- Dowry for daughters ready for marriage is low due to low prices of poor quality crops and livestock and consequent low income.

\subsection{Farmers Coping Strategies/Opportunities}

The indigenous knowledge base in some part of West Africa with the use of biological and social data have also helped in the adoption of mitigation strategies and conservation of biodiversity that may have resulted from climate change [15]. Adaptive responses to delay or shortening of the rainy season in the communities surveyed include;

- Evolving contingency cropping systems - when rains are delayed, they use early maturing crop varieties or change the crops grown - instead of millet, use early maturing dwarf sorghum variety (Mace da kunya in Sokoto) once it germinates and starts growing, it can withstand drought till harvest time.

- Rainfall variability in the communities has also altered the farming systems, either in terms of changes in cropping pattern, elimination/reduction in the level of production of some crops or introduction of new crop varieties that are drought resistant and early maturing.

- Relay cropping was a common practice in the communities about ten years ago but this has been eliminated as a result of low distribution of rainfall. For instance, the farmers used to cultivate millet and harvest before planting cowpea (Vigna unguiculata). Some farmers even use the proceeds from millet to invest in cowpea production. With reduction in the amount of rain, all these crops are now intercropped on the same plot.

- The level of sugarcane production has decreased as a result of reduction in the quantity of water for irrigation. They now cultivate more vegetables like pepper, onion, tomato which does not require as much water as sugarcane.

- Migration of pastoralists and their animals out of the community in search of feed and water. In case of drought, arable farmers also move to areas where there are no problems with rainfall for rainfed farming and return after the season.

- Diversification of income - trading, artisans, digging tube wells for money, packing sand and selling etc.

\section{CONCLUSION}

This paper has attempted to assess farmers' knowledge and skills on rainfall prediction, variability and coping strategies. It is evident from the findings of the survey 
that farmers have evolved several indicators for predicting onset of rains and planting season. However, the people were of the opinion that the level of accuracy is lower now than before with the erratic nature of weather in the present days. This is a clear evidence of the reality of global climate change phenomenon in the survey area. In case of wrong prediction or poor rainfall, farmers were forced to adapt various coping strategies to sustain their livelihood. Even where the communities have access to scientific weather forecast, some farmers still adhered to forecast of local experts in making farm management decision. Farmers therefore recommended an integration of traditional proven methods of rainfall prediction with scientific methods to evolve reliable forecast that will reduce risks in their rain fed farming systems.

\section{ACKNOWLEDGEMENTS}

The International START Secretariat supported this work under the START/PACOM Award 2005 for a project through a grant from the US NSF (GEO-0203288 "Capacity Building for Global Change"). We also like to acknowledge the contribution of Professor. S. A. Ibrahim, Drs. J. M. Jibrin, A. I. Yakubu, and S. Miko who are researcher from the University within the states were the study was carried out. Their active participation in the community survey is duly acknowledged. We appreciate the contribution of the extension agents of SG 2000, (NGO working in the state) during the field work.

\section{REFERENCES}

[1] Hess, T.M., William Stephens and U.M. Maryah (1995) Rainfall trends in the North East arid zone of Nigeria 1961-1990. Agricultural and Forest Meteorology. 74, 8797. doi:10.1016/0168-1923(94)02179-N

[2] Nicholson, S.E., Some, B. and Kone, B. (2000) An analysis of recent rainfall conditions in West Africa, including the rainy seasons of the 1997 El Niño and the 1998 La Niña years. Journal of Climate, 13, 2628-2640. doi:10.1175/1520-0442(2000)013<2628:AAORRC $>2.0$. $\mathrm{CO} ; 2$

[3] Dore, M.H.I. (2005) Climate change and changes in global precipitation patterns: What do we know? Environment International, 31, 1167-1181. doi:10.1016/j.envint.2005.03.004

[4] Oluwasemire, K.O., Stigter, C.J., Owonubi, J.J. and Jagtap, S.S. (2002) Seasonal water use and water productivity of millet based intercropping systems in the Nigerian Sudan
Savanna near Kano. Agricultural Water Management, 56, 207-227. doi:10.1016/S0378-3774(02)00008-2

[5] Nnoli, N.O. (2004) Variability and change in mean onset and cessation dates of rainy season in Nigeria. Nigerian Meteorological Journal, 4, 36-49.

[6] Nnaji, A.O. (2001) Forecasting seasonal rainfall for agricultural decision-making in northern Nigeria. Agricultural and Forest Meteorology, 107, 193-205. doi:10.1016/S0168-1923(00)00239-2

[7] Food and Agriculture Organization (1998) Report on the development of food insecurity and vulnerability. Committee on world food security, Rome.

http://www.fao.org/docrep/meeting/w84970.htm

[8] Okorie, F.C. (2002) Studies on drought in Sub-Saharan region of Nigeria using statelite remote sensing and precipitation data.

http://www.mathaba.net/gci/docs/research/nigeria-drough t.htm

[9] Dietz, A.J., Ruben, R. and Verhagen, A. (2001) Impact of climate change on dry lands with focus on West Africa. Global air pollution and climate change. Report No. 410200076, Wageningen.

[10] Fiki, C. and Lee, B. (2004) Conflict generation conflict management and self organization capabilities in drought prone rural communities in north east Nigeria. Journal of Social Development in Africa, 19, 25-48.

[11] Breman, H. and Kessler, J.J. (1995) Woody plants in agroecosystems of semi-arid regions with emphasis on the Sahelian countries. Springer-Verlag, Berlin.

[12] Morton, J.F. (2007) The impact of climate change on smallholder and subsistence agriculture. Proceedings of the National Academy of Sciences of the United States of America, 104, 19680-19685. doi:10.1073/pnas.0701855104

[13] Mutiso, S.K. (1996) Indigenous knowledge in drought and famine forecasting in Machakos District, Kenya. Indigenous knowledge and change in African agriculture. In: Adams, W.M. and Slikkerveer, L.J., Eds., Technology and Social Change Program, Iowa State University, Ames, 67-86.

[14] Nyong, A., Adesina, F. and Elasha, B.O. (2007) The value of indigenous knowledge in climate change mitigation and adaptation strategies in the African sahel. Mitigation and Adaptation Strategies for Global Change, 12, 787 797. doi:10.1007/s11027-007-9099-0

[15] Amanor, K. (1994) The new frontier: Farmer responses to land degradation: A West African study. Zeb Books, London. 